\title{
Effect of Starvation, Refeeding and Hydrocortisone Administration on Turnover of Myofibrillar Proteins Estimated by Urinary Excretion of $N^{\tau}$-Methylhistidine in the Rat
}

\author{
Naoyuki Nishizawa, Mamoru Shimbo, Tadashi Noguchi, \\ Shin-ichi Hareyama and Ryuhei Funabiki* \\ Department of Agricultural Chemistry, Iwate University, Morioka, Iwate, Japan \\ *Department of Agricultural Chemistry, Tokyo Noko University, \\ Fuchu-shi, Tokyo, Japan
}

Received June 14, 1978

1. Quantitative changes in fractional catabolic and synthetic rates of the myosin-actin pool in rat muscle under starvation and refeeding, during growth or after treatment with hydrocortisone were studied by estimating urinary excretion of $N^{\tau}$-methylhistidine (3-methylbistidine; Me-His).

2. Following deprivation of food, urinary Me-His output increased from $0.35 \mathrm{mg} / \mathrm{day}$ to $0.45 \mathrm{mg} /$ day during first 2 day in spite of decreasing body $\mathrm{Me}-\mathrm{His}$ pool. This high rate of Me-His excretion was maintained for the following 4 days of starvation and then decreased. When rats were refed a $20 \%$ casein diet after 10 days of starvation, Me-His excretion continued to decrease even after 3 days of refeeding. On the fifth day of refeeding, it began to rise progressively. During starvation, fractional catabolic rate of myosin-actin was about $3.7 \%$ day in comparison with $2.6 \%$ day of fed rats. After refeeding, the fractional catabolic rate decreased rapidly to a minimum value of $1.7 \%$ day on the third day. After that, it reached to a value of $2.6 \%$ day of fed rats. On the other hand, fractional synthetic rate of myosin-actin dropped immediately after fasting and the low rate of about $0.4 \% /$ day was maintained during starvation period. Fractional synthetic rate recovered quickly after refeeding.

3. Urinary output of nitrogen and creatinine rose quickly on the first day after administration of hydrocortisone and on the second day it fell to their normal value. While Me-His excretion increased after injection of hydrocortisone up to $0.52 \mathrm{mg} /$ day on the second day and this high excretion rate remained until the following day. From these results, it was shown that administration of hydrocortisone to rats enhances catabolism and reduces synthesis of myosin-actin. The results also show that the effect of this hormone on myofibrillar protein catabolism appears to last longer than its effect on nitrogen metabolism in the whole body judged from urinary nitrogen output.

4. Fractional rates of catabolism and synthesis of rat myosin-actin were $3.3 \% /$ day (halflife of 21 days) and $7.2 \% /$ day, respectively, at the growth stage of $129 \mathrm{~g}$ body weight. These rates were $2.3 \%$ day (half-life of 30 days) and $2.8 \%$ day, respectively, at the mature stage of $363 \mathrm{~g}$ body weight.

5. Under the dietary conditions in this experiment, fractional synthetic rate changed far more dramatically than catabolic rate. This suggests that mass of muscle protein is primarily regulated by the rate of synthesis, although the rate of catabolism should not be neglected.

There are many studies on in vivo synthetic or catabolic rates of mixed proteins as well as myosin and actin in skeletal muscle under various nutritional conditions.

Waterlow and Stephen ${ }^{1,2)}$ showed a large reduction in protein synthetic rate in skeletal muscle when rats were given low-protein or protein-free diets. Young et al. $^{3{ }^{3}}$ reported that protein synthesis recovered greatly and catabolism apparently ceased temporarily, when protein-depleted rats were refed an adequate diet for several days. Decrease in synthetic 
rate of muscle protein during fasting or protein depletion has also been reported by Millward et al. ${ }^{4)}$ and Garlick et al. ${ }^{5}$ Millward et al. ${ }^{4)}$ also showed that synthetic rate of muscle protein increased promptly on refeeding a proteincontaining diet after 21 days protein depletion. Catabolic rates of myosin-actin under various nutritional conditions have also been estimated by determining urinary excretion of $N^{\tau}$ methylhistidine (3-methylhistidine; Me-His). By this method, Haverberg et $a l^{(6)}$ studied catabolic rate of myosin-actin during proteinenergy restriction and repletion from it. Funabiki et al. ${ }^{7}$ also showed both rates of degradation and synthesis of these proteins during the course of protein depletion and repletion.

On early stage of food deprivation, it has been well recognized that synthetic rate of muscle proteins decreases rapidly and the catabolic rate increases. ${ }^{5,8,9}$ However, the changes in those rates during prolonged starvation and the subsequent refeeding have not been quantitatively estimated.

Synthetic and catabolic rates of muscle proteins are also studied during the course of growth. Millward et al., ${ }^{10}$, with growing rats on an adequate diet, reported that both synthetic and catabolic rates of skeletal muscle proteins fell with age. They suggested that high rate of muscle protein synthesis in younger stages is accompanied by high rate of protein catabolism.

Hormonal factors are also well known to regulate muscle protein synthesis and catabolism. ${ }^{11)}$ Insulin and growth hormone act as anabolic agents and glucocorticoid acts in the opposite manner. However, it is not well documented whether muscle protein synthesis increases or breakdown decreases under various hormonal conditions.

All of these studies strengthen the importance of both synthesis and degradation of muscle proteins in order to elucidate the physiological state of whole animal.

Since the suggestion of the potential usefulness of urinary Me-His for estimation of catabolic rate of skeletal muscle protein, ${ }^{12}$ confirmatory evidences of the method have been reported by several authors. ${ }^{13 \sim 18)}$ Catabolic rates of myosin-actin of skeletal muscle under various nutritional, clinical or pathological conditions have been estimated by this method. ${ }^{6,7,16 \sim 24)}$

The present studies extend our previous studies, as well as those from other laboratories, on the fractional rates of catabolism and synthesis of myosin-actin under various nutritional and hormonal conditions. The results revealed quantitative changes in the fractional rates under various physiological conditions of animals.

\section{METHODS}

Animals and diet. Male Wistar rats were used for all experiments. They were individually housed in stainless-steel cages in air-conditioned room maintained at $22 \pm 1^{\circ} \mathrm{C}$. They were nourished with a $20 \%$ casein diet as described previously. $\left.{ }^{2 B}\right)$ This diet will be referred to as casein diet. The salt and vitamin mixtures were prepared according to National Academy of Sciences. ${ }^{28)}$

Feedings. Animals were divided into three experimental groups as follows. (I) Six rats of mean $320 \mathrm{~g}$ body weight of starvation-refeeding group were starved for 10 days. After that, they were refed casein diet ad libitum for 10 days. During starvation and the subsequent refeeding, $24 \mathrm{hr}$ urine samples were collected in flasks containing $2 \mathrm{ml}$ of $4 \mathrm{M} \mathrm{HCl}$ every 1 or 2 days and stored at $-20^{\circ} \mathrm{C}$ until they were analyzed. (II) Five rats of mean $370 \mathrm{~g}$ body weight of hydrocortisone group, which were fed casein diet, were received a single subcutaneous injection of $3 \mathrm{mg}$ hydrocortisone (Wako Pure Chemical Industries Co. Ltd., Osaka, Japan)/ $100 \mathrm{~g}$ body weight and thereafter given ad libitum casein diet for 5 days. During these experimental periods, $24 \mathrm{hr}$ urine samples were collected every 1 or 2 days. These urine samples were stored at $-20^{\circ} \mathrm{C}$ until required for analysis. (III) Six immature rats of mean $75 \mathrm{~g}$ body weight for growth studies were given casein diet ad libitum for 84 days. Every 10 or 20 days, $24 \mathrm{hr}$ urine samples were collected and stored at $-20^{\circ} \mathrm{C}$ until they were analyzed.

Analytical procedures. Me-His, nitrogen and creatinine in urine samples were determined according to the method described previously. ${ }^{16)}$

Fractional catabolic and synthetic rates of myosinactin in skeletal muscle were calculated by the method of a previous paper. ${ }^{7)}$. When calculating fractional catabolic rate of myosin-actin from the urinary excretion of Me-His, we have to take into account the 
amount of urinary Me-His released from other tissues than skeletal muscle, especially skin and gastrointestine. ${ }^{25)}$ However, it still remains to be elucidated how much urinary Me-His is originated from the tissues other than skeletal muscle under some physiological conditions; e.g. starvation or after glucocorticoid injection. Therefore, in the present investigation, the results were corrected only in the case of studying catabolic rates of myosin-actin during growth, assuming that $16.6 \%$ of urinary Me-His is excreted from the tissues other than skeletal muscle. ${ }^{25)}$

Student's $t$ test was used for statistical analyses of the results. ${ }^{27}$ )

\section{RESULTS}

Changes in body weight and urinary excretion of Me-His, creatinine and nitrogen during starvation and the subsequent refeeding

Table I shows the changes in body weight and urinary output of Me-His, creatinine and nitrogen during starvation and the subsequent refeeding. Body weight decreased rapidly at a rate of mean $9.1 \mathrm{~g} /$ day on fasting and it recovered quickly at a rate of about $9.1 \mathrm{~g} /$ day after refeeding. On the other hand, excretion of Me-His increased from $0.35 \mathrm{mg} /$ day to $0.45 \mathrm{mg}$ /day during first 2 days after fasting and reached a plateau. This rate of $\mathrm{Me}-\mathrm{His}$ excretion persisted until the sixth day after the beginning of starvation and the rate decreased thereafter until the third day of refeeding. After then, the excretion rate rose again gradually and reached at the normal rate of $0.35 \mathrm{mg} /$ day after 10 days of refeeding. Creatinine output during starvation and the subsequent refeeding showed similar changes to that of body weight. However, in contrast with urinary $\mathrm{Me}-\mathrm{His}$, creatinine output per unit body weight remained almost constant at a value of $3.1 \mathrm{mg} / 100 \mathrm{~g}$ body weight during the experimental period.

Table I. Changes in Body Weight and Daily Urinary Output of $N^{\tau}$-Methylhistidine (Me-His), Creatinine and Nitrogen in Rats During StaRvation and the Subsequent Refeeding with A $20 \%$ CASEIN DIET ${ }^{a}$

\begin{tabular}{|c|c|c|c|c|c|c|c|}
\hline \multirow[b]{2}{*}{$\begin{array}{c}\text { Days of } \\
\text { experiment }\end{array}$} & \multirow[b]{2}{*}{$\begin{array}{l}\text { Body } \\
\text { wt. } \\
\text { (g) }\end{array}$} & \multicolumn{2}{|c|}{ Urinary Me-His } & \multicolumn{2}{|c|}{ Urinary creatinine } & \multicolumn{2}{|c|}{ Urinary nitrogen } \\
\hline & & $\begin{array}{l}\text { Total } \\
\text { amount } \\
\text { (mg) }\end{array}$ & $\begin{array}{l}\text { Amount } \\
\text { relative to } \\
\text { body wt. } \\
\text { (mg/100 g } \\
\text { body wt.) }\end{array}$ & $\begin{array}{c}\text { Total } \\
\text { amount } \\
\text { (mg) }\end{array}$ & $\begin{array}{l}\text { Amount } \\
\text { relative to } \\
\text { body wt. } \\
\text { (mg/100g } \\
\text { body wt.) }\end{array}$ & $\begin{array}{c}\text { Total } \\
\text { amount } \\
\text { (mg) }\end{array}$ & $\begin{array}{l}\text { Amount } \\
\text { relative to } \\
\text { body wt. } \\
\text { (mg/100 g } \\
\text { body wt.) }\end{array}$ \\
\hline \multicolumn{8}{|c|}{ Starvation phase } \\
\hline 0 & $320 \pm 5$ & $0.352 \pm 0.007$ & $0.110 \pm 0.001$ & $10.0 \pm 0.39$ & $3.12 \pm 0.09$ & $508 \pm 22$ & $159 \pm 7$ \\
\hline 1 & $303 \pm 4$ & $0.340 \pm 0.016$ & $0.112 \pm 0.004$ & $9.72 \pm 0.50$ & $3.20 \pm 0.13$ & $187 \pm 7$ & $61.7 \pm 2.7$ \\
\hline 2 & $292 \pm 5$ & $0.455 \pm 0.062$ & $0.154 \pm 0.021^{1 c}$ & $9.71 \pm 0.88$ & $3.32 \pm 028$ & $130 \pm 8$ & $44.6 \pm 3.0$ \\
\hline 4 & $272 \pm 5$ & $0.430 \pm 0.043$ & $0.158 \pm 0.014^{1}$ & $8.41 \pm 0.72$ & $3.08 \pm 0.23$ & $110 \pm 8$ & $40.6 \pm 3.2$ \\
\hline 6 & $257 \pm 5$ & $0.414 \pm 0.042$ & $0.161 \pm 0.016^{1}$ & $8.68 \pm 0.88$ & $3.37 \pm 0.32$ & $101 \pm 7$ & $39.3 \pm 2.7$ \\
\hline 8 & $241 \pm 4$ & $0.348 \pm 0.040$ & $0.144 \pm 0.015$ & $6.73 \pm 0.85$ & $2.78 \pm 0.34$ & $93.3 \pm 9.3$ & $39.0 \pm 3.5$ \\
\hline 10 & $229 \pm 4$ & $0.361 \pm 0.032$ & $0.156 \pm 0.011^{2}$ & $6.38 \pm 0.89$ & $2.76 \pm 0.35$ & $85.6 \pm 10.8$ & $37.1 \pm 4.3$ \\
\hline \multicolumn{8}{|c|}{ Refeeding phase } \\
\hline 11 & $253 \pm 4$ & $0.337 \pm 0.024$ & $0.133 \pm 0.009^{1}$ & $7.76 \div 0.84$ & $3.06=0.33$ & $\mathrm{ND}^{a^{2}}$ & \\
\hline 12 & $260 \pm 4$ & $0.193 \pm 0.012$ & $0.074 \pm 0.004^{3}$ & $8.39 \pm 0.63$ & $3.24 \pm 0.43$ & ND & \\
\hline 13 & $269 \pm 3$ & $0.196 \pm 0.018$ & $0.073 \pm 0.006^{3}$ & $8.99 \pm 0.43$ & $3.35 \pm 0.17$ & ND & \\
\hline 15 & $281 \pm 3$ & $0.280 \pm 0.013$ & $0.099 \pm 0.004$ & $9.57 \pm 0.39$ & $3.41 \pm 0.12$ & ND & \\
\hline 17 & $296 \pm 4$ & $0.321 \pm 0.016$ & $0.109 \pm 0.005$ & $9.11 \pm 0.36$ & $3.07 \pm 0.12$ & $\mathrm{ND}$ & \\
\hline 20 & $320 \pm 5$ & $0.350 \pm 0.015$ & $0.109 \pm 0.003$ & $9.52 \pm 0.60$ & $2.96 \pm 0.15$ & ND & \\
\hline
\end{tabular}

a Mean \pm SE for six rats.

$b$ No significance of differences from 0 day of experiment.

- Significance of differences from 0 day of experiment: ${ }^{1} \mathrm{p}<0.05 ;{ }^{2} \mathrm{p}<0.01 ;{ }^{3} \mathrm{p}<0.001$.

d ND, not determined. 
Changes in fractional catabolic and synthetic rates of myosin-actin during starvation and the subsequent refeeding

Figure 1 shows the changes in fractional catabolic and synthetic rates of myosin-actin during starvation and the subsequent refeeding.

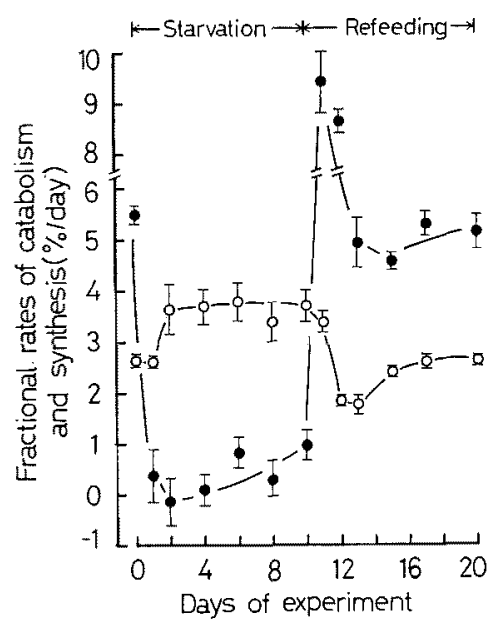

Fig. 1. Changes in Fractional Rates of Catabolism (O) and Synthesis (•) of Myosin-actin in Skeletal Muscle of Rats during Starvation and the Subsequent Refeeding with a $20 \%$ Casein Diet.

Points are mean values with their standard errors for six rats.

After the beginning of starvation, fractional catabolic rate increased from $2.6 \%$ day to about $3.7 \%$ day and this high rate was sustained during the period of starvation. By re- feeding, the catabolic rate decreased rapidly. The rate continued to fall during initial 3 days of refeeding and reached to $1.7 \%$ /day on the third day of refeeding. On the fifth day of refeeding, catabolic rate recovered and showed almost normal value of $2.4 \%$ day. In contrast with catabolism, the synthesis of myosin-actin dropped immediately after fasting and the situation of low rate of about $0.4 \%$ day lasted during the period of starvation. At the end of starvation, the synthetic rate showed approximately $1 \%$ /day. By refeeding, fractional synthetic rate increased immediately up to $9.4 \% /$ day and thereafter kept a constant rate of approximately $5 \% /$ day. These results showed that catabolism and synthesis of myosin-actin during starvation and the subsequent refeeding responded in opposite directions.

Changes in body weight and urinary excretion of Me-His, creatinine and nitrogen after single injection of hydrocortisone

Table II shows the changes in body weight and urinary output of $\mathrm{Me}-\mathrm{His}$, creatinine and nitrogen after injection of hydrocortisone. Body weight decreased at a rate of $4 \mathrm{~g} /$ day by this treatment. This decrease in body weight is due at least partially to the reduction in food intake after administration of this hormone. Mean food intake decreased from 20 to $11 \mathrm{~g} /$ day during this period. Me-His excretion rose by this treatment and reached a maximum

Table II. Changes in Body Weight and Daily Urinary OUtPut of $N^{\tau}$-Methylhistidine (Me-His), Creatinine and Nitrogen after Single AdMINISTRATION OF Hydrocortisone $3 \mathrm{mg} / 100 \mathrm{~g}$

BODY WEIGHT TO RATS ${ }^{\alpha}$

\begin{tabular}{|c|c|c|c|c|c|c|c|}
\hline \multirow[b]{2}{*}{$\begin{array}{l}\text { Days of } \\
\text { experiment }\end{array}$} & \multirow[b]{2}{*}{$\begin{array}{l}\text { Body } \\
\text { wt. } \\
\text { (g) }\end{array}$} & \multicolumn{2}{|c|}{ Urinary Me-His } & \multicolumn{2}{|c|}{ Urinary creatinine } & \multicolumn{2}{|c|}{ Urinary nitrogen } \\
\hline & & $\begin{array}{l}\text { Total } \\
\text { amount } \\
\text { (mg) }\end{array}$ & $\begin{array}{c}\text { Amount } \\
\text { relative to } \\
\text { body wt. } \\
\text { (mg/100 g } \\
\text { body wt.) }\end{array}$ & $\begin{array}{l}\text { Total } \\
\text { amount } \\
\text { (mg) }\end{array}$ & $\begin{array}{l}\text { Amount } \\
\text { relative to } \\
\text { body wt. } \\
\text { (mg/100 g } \\
\text { body wt.) }\end{array}$ & $\begin{array}{l}\text { Total } \\
\text { amount } \\
\text { (mg) }\end{array}$ & $\begin{array}{l}\text { Amount } \\
\text { relative to } \\
\text { body wt. } \\
\text { (mg/100 g } \\
\text { body wt.) }\end{array}$ \\
\hline 0 & $370 \pm 6$ & $0.364 \pm 0.030$ & $0.098 \pm 0.007$ & $7.70 \pm 0.54$ & $2.00 \pm 0$ & $332 \pm 18$ & $89.7 \pm 5.4$ \\
\hline 1 & $366 \pm 6$ & $0.487 \pm 0.008$ & $0.132 \pm 0.003^{3 b}$ & $9.34 \pm 0.84$ & $2.55 \pm 0.25^{2}$ & $431 \pm 49$ & $117 \pm 16^{1}$ \\
\hline 2 & $357 \pm 7$ & $0.522 \pm 0.036$ & $0.146 \pm 0.008^{2}$ & $6.77 \pm 0.38$ & $1.89 \pm 0.10$ & $290 \pm 32$ & $81.3 \pm 8.9$ \\
\hline 3 & $353 \pm 7$ & $0.526 \pm 0.053$ & $0.149 \pm 0.016^{2}$ & $7.61 \pm 0.36$ & $2.15 \pm 0.10$ & $283 \pm 48$ & $80.0 \pm 13.2$ \\
\hline 5 & $350 \pm 9$ & $0.394 \pm 0.026$ & $0.113 \pm 0.008$ & $6.89 \pm 0.37$ & $1.97 \pm 0.11$ & $307 \pm 51$ & $87.5 \pm 12.8$ \\
\hline
\end{tabular}

a Mean \pm SE for five rats.

${ }_{b}^{b}$ Significance of differences from 0 day of experiment: ${ }^{1} \mathrm{p}<0.05 ;{ }^{2} \mathrm{p}<0.01 ;{ }^{3} \mathrm{p}<0.001$. 
value of $0.52 \mathrm{mg} /$ day on the second day. This excretion rate was maintained up to the following third day and, thereafter, it regressed to normal value. On the other hand, creatinine and nitrogen excretion into urine rose on the first day after injection and on the second day it returned to their normal values.

\section{Changes in fractional catabolic and synthetic} rates of myosin-actin after hydrocortisone injection

As given in Fig. 2, fractional catabolic rate of myosin-actin after administration of this glucocorticoid increased and the rate showed a maximum value of $3.5 \% /$ day on the second day. This high rate of catabolism was maintained up to the next day. The synthetic rate decreased during the first 2 days and recovered quickly, thereafter.

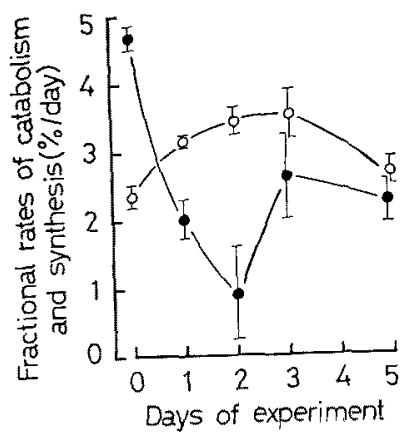

Fig. 2. Changes in Fractional Rates of Catabolism (O) and Synthesis (e) of Myosin-actin in Skeletal Muscle after Single Administration of Hydrocortisone of $3 \mathrm{mg} / 100 \mathrm{~g}$ Body Weight to Rats.

Points are mean values with their standard errors for five rats.

Fractional rates of catabolism and synthesis of myosin-actin during growth

Urinary excretion of Me-His rose in almost parallel fashion with body weight gain (Table III).

As given in Fig. 3, fractional catabolic rate of myosin-actin on the growth stage of $129 \mathrm{~g}$ body weight was $3.3 \%$ /day (half-life of 21 days), while the synthetic rate was $7.2 \% /$ day. Thereafter, both catabolic and synthetic rates decreased as rats grew older. The decrease in synthetic rate was faster than that in catabolic
Table III. Changes in Body Weight and DaIly URINARY OUTPUT OF $N^{\tau}$-MethylHISTIDINE (Me-His) DURING Growth OF Rats GIVEN ad libitum A $20 \%$ CASEIN DIET ${ }^{a}$

\begin{tabular}{|c|c|c|c|}
\hline \multirow[b]{2}{*}{$\begin{array}{l}\text { Days of } \\
\text { experi- } \\
\text { ment }\end{array}$} & \multirow[b]{2}{*}{$\begin{array}{c}\text { Body } \\
\text { wt. } \\
\text { (g) }\end{array}$} & \multicolumn{2}{|c|}{ Urinary Me-His } \\
\hline & & $\begin{array}{c}\text { Total } \\
\text { amount } \\
(\mathrm{mg})\end{array}$ & $\begin{array}{l}\text { Amount relative } \\
\text { to body wt. } \\
\text { (mg/100g } \\
\text { body wt.) }\end{array}$ \\
\hline 0 & $75 \pm 2$ & $0.108=0.010$ & $0.144 \pm$ \\
\hline 11 & $129 \pm 5$ & $0.212 \pm 0.013$ & $0.164 \pm 0.005$ \\
\hline 22 & $176 \pm 10$ & $0.247 \pm 0.022$ & $0.140 \pm 0.005$ \\
\hline 32 & $210 \pm 15$ & $0.289 \pm 0.041$ & $0.137 \pm 0.012$ \\
\hline 43 & $260 \pm 15$ & $0.320 \pm 0.029$ & $0.123 \pm 0.008$ \\
\hline 63 & $324 \pm 9$ & $0.370 \pm 0.013$ & $0.114 \pm 0.006$ \\
\hline 84 & $363 \pm 13$ & $0.420 \pm 0.017$ & $0.115 \pm 0.006$ \\
\hline
\end{tabular}

a Mean $\pm S E$ for six rats.

rate. When rats weighed $363 \mathrm{~g}$, fractional catabolic and synthetic rates were $2.3 \%$ /day (half-life of 30 days) and $2.8 \% /$ day, respectively.

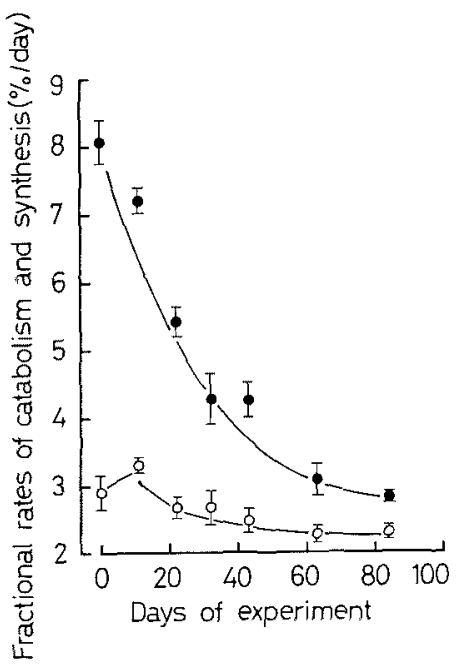

FIG. 3. Changes in Fractional Rates of Catabolism (O) and Synthesis ( of Myosin-actin in Skeletal Muscle during Growth of Rats Given ad libitum a $20 \%$ Casein Diet.

Points are mean values with their standard errors for six rats.

\section{DISCUSSION}

Although nitrogen balance studies give many informations on the protein metabolism of whole body, they bring about little knowledge 
concerning the synthetic or catabolic rates of proteins in various organs and tissues, as well as skeletal muscle tissue.

As discussed earlier in this paper, it is now widely believed that urinary excretion of MeHis is a valuable method to estimate catabolic rate of myosin-actin. Funabiki et al. ${ }^{7}$ extended this method to quantitative estimation of the synthetic rate of myosin-actin pool of the body and demonstrated that synthetic rate of myosin-actin decreased rapidly after protein deprivation and recovered very quickly upon refeeding a protein diet. The changes in urinary Me-His excretion during prolonged starvation and the subsequent refeeding (Table I) were different from those of the case in protein deprivation. ${ }^{7)}$ The results of the present study were similar to the case of restricted protein and energy intake. ${ }^{6}$ It has been well recognized that starvation brings about increase in the catabolism and decrease in synthesis of muscle protein..$^{5,8,9}$ However, quantitative estimation of the synthetic and catabolic rates of myosin-actin during starvation and the subsequent refeeding is not yet reported in detail. The present study revealed that the synthesis of myosin-actin in skeletal muscle drops immediately after fasting (Fig. 1). This is not consistent with the results reported by Millward, ${ }^{87}$ Garlick et al. ${ }^{5}$ and Millward et al. ${ }^{97}$ They showed progressive decrease in the synthetic rate of mixed muscle protein after fasting. On the other hand, the present results showed as follows. Fractional catabolic rate increased during first 2 day of fasting and reached a plateau of about $3.7 \%$ /day. This rate was maintained during the period of starvation. The rate continued to decrease even after refeeding of casein diet. After the fifth day of refeeding, fractional catabolic rate began to increase. These results show that, although skeletal muscle loses its protein both in the case of fasting or protein deprivation, the mechanism of loss is different in these two cases.

Quick response of urinary nitrogen excretion to injection of hydrocortisone (Table II) may suggest rapid degradation of body proteins other than myofibrils. Urinary output of Me-His showed that catabolism of myosinactin increases during first 3 days of this treatment and falls to the normal value thereafter (Table II). Influence of corticosteroids on catabolism of muscle protein has been well known. ${ }^{11,28)}$ The present studies suggest that the effect of hydrocortisone lasts longer on the muscle protein catabolism than that on the protein catabolism of the other organs judged from total nitrogen output. The present results, consistent with Goldberg, ${ }^{29)}$ showed that hydrocortisone not only increases muscle protein catabolism but also decreases muscle protein synthesis. However, further studies using various levels of hydrocortisone will be required to conclude generally, since DeLoecker ${ }^{30}$ ) showed that the effect of hydrocortisone on catabolism and synthesis depends on the amount of this agent used.

As calculated from Fig. 3, the amount of myosin-actin in skeletal muscle increases at a rate of $3.8 \%$ day at the growing stage of $129 \mathrm{~g}$ body weight and $0.5 \%$ day at the stage of $363 \mathrm{~g}$ body weight. Further, as extrapolated from Fig. 3 and Table III, it was suggested that the fractional synthetic rate of myosin-actin at $400 \mathrm{~g}$ body weight would reach to a rate of $2.3 \% /$ day which equals with the fractional catabolic rate.

Changes in synthetic rate of myosin-actin were greater than those in catabolism under the conditions described in the present paper (Figs. 1, 2 and 3). Although the amount of muscle protein is regulated by both rates of synthesis and catabolism, fractional synthetic rate changed more quickly and profoundly than catabolic rate. Therefore, consistent with Millward et al., ${ }^{9}$ ' it seems that the primary factor for regulating muscle protein mass is the rate of synthesis.

Catabolic rates of myosin and actin have been estimated by many authors using isotopic techniques. Results shown in the present investigation are consistent with isotope studies in many cases. However, isotope studies come into confliction with amino acid reutilization, especially when physiological states of animals 
are changing. Estimations of both catabolic and synthetic rates of myosin-actin from urinary excretion of Me-His will bring about great advances in understanding muscle protein metabolism under various nutritional or physiological conditions.

\section{REFERENCES}

1) J. C. Waterlow and J. M. L. Stephen, $B r . J$. Nutr., 20, 461 (1966).

2) J. C. Waterlow and J. M. L. Stephen, Clin. Sci., 35, 287 (1968).

3) V. R. Young, S. C. Stothers and G. Vilaire, J. Nutr., 101, 1379 (1971).

4) D. J. Millward, P. J. Garlick, W. P. T. James, D. O. Nnanyelugo and J. S. Ryatt, Nature, 241, 204 (1973).

5) P. J. Garlick, D. J. Millward, W. P. T. James and J. C. Waterlow, Biochim. Biophys. Acta, 414, 71 (1975).

6) L. N. Haverberg, L. Deckelbaum, C. Bilmazes, H. N. Munro and V. R. Young, Biochem. J., 152, 503 (1975).

7) R. Funabiki, Y. Watanabe, N. Nishizawa and S. Hareyama, Biochim. Biophys. Acta, 451, 143 (1976).

8) D. J. Millward, Clin. Sci., 39, 591 (1970).

9) D. J. Millward, P. J. Garlick, D. O. Nnanyelugo and J. C. Waterlow, Biochem. J., 156, 185 (1976).

10) D. J. Millward, P. J. Garlick, R. J. C. Stewart, D. O. Nnanyelugo and J. C. Waterlow, ibid., 150, 235 (1975).

11) V.R. Young, "Mammalian Protein Metabolism," Vol. 4, ed. by H. N. Munro, Academic Press Inc., New York, N. Y., 1970, p. 585.

12) A. M. Asatoor and M. D. Armstrong, Biochem. Biophys. Res. Commun., 26, 168 (1967).

13) V. R. Young, S. D. Alexis, B. S. Baliga, H. N. Munro and W. Muecke, J. Biol. Chem., 247, 3592 (1972).
14) L. N. Haverberg, P. T. Omstedt, H. N. Munro and V. R. Young, Biochim. Biophys. Acta, 405, 67 (1975).

15) C. L. Long, L. N. Haverberg, V. R. Young, L. M. Kinney, H. N. Munro and J. W. Geiger, Metab. Clin. Exp., 24, 929 (1975).

16) N. Nishizawa, M. Shimbo, S. Hareyama and R. Funabiki, Br. J. Nutr., 37, 345 (1977).

17) B.S. Narasinga Rao and V.S. Nagabhushan, Life Sci., 12, 205 (1973).

18) V. R. Young, L. N. Haverberg, C. Bilmazes and H. N. Munro, Metab. Clin. Exp., 22, 1429 (1973).

19) N. Nishizawa, R. Funabiki and S. Hareyama, J. Nutr. Sci. Vitaminol, 21, 383 (1975).

20) R. W. Wannemacher, Jr., R. E. Dinterman, R. S. Pekarek, P. J. Bartelloni and W. R. Beisel, Am. $J$. Clin. Nutr., 28, 110 (1975).

21) G. F. Fitzpatrick, M. M. Meguid, P. H. Gitlitz and M. F. Brennan, Metab. Clin. Exp, 26, 477 (1977).

22) C. L. Long, W. R. Schiller, W.S. Blakemore, J. W. Geiger, M. O'Dell and K. Henderson, $A m$. J. Clin. Nutr., 30, 1349 (1977).

23) S. J. Wassner, S. Orloff and M. A. Holliday, Am. J. Physiol., 233, E199 (1977).

24) D. H. Williamson, R. Farrel, A. Kerr and R. Smith, Clin. Sci. Mol. Med., 52, 527 (1977).

25) N. Nishizawa, T. Noguchi, S. Hareyama and R. Funabiki, Br. J. Nutr., 38, 149 (1977).

26) National Academy of Sciences, "Nutrient Requirements of Domestic Animals No. 10: Nutrient Requirements of Laboratory Animals,"' 2nd ed., National Academy of Sciences, Washington, D.C., 1972, p. 64.

27) G.W. Snedecor and W. G. Cochran, "Statistical Methods, 6th ed.," The lowa State University Press, Ames, Iowa, 1967, Chapter 4.

28) M. Mayer and F. Rosen, Metab. Clin. Exp., 26, 937 (1977).

29) A. L. Goldberg, J. Biol. Chem., 244, 3223 (1969).

30) W. DeLoecker, Acta Endocrinol., 52, 416 (1966). 